


\section{THERMAL CONDUCTIVITY OF GLASS FIBER/EPOXY COMPOSITE SUPPORT BANDS FOR CRYOGENIC DEWARS, PHASE II}

\section{J. G Hust}

Chemical Engineering Science Division National Engineering Laboratory

National Bureau of Standards

U.S. Department of Commerce

Boulder, Colorado 80303

March 1984

Sponsored by:

National Aeronautics and Space Administration

Goddard Space Flight Center

Greenbelt, Maryland 20771

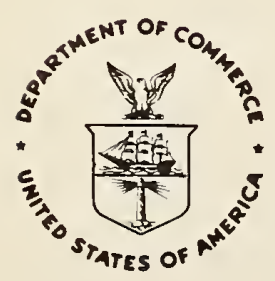

U.S. DEPARTMENT OF COMMERCE, Malcolm Baldrige, Secretary 

CONTENTS

Page

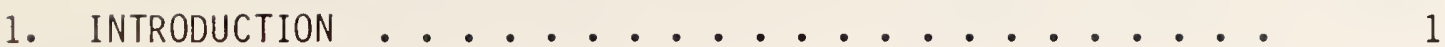

2. MATERIAL AND SPECIMEN CHARACTERIZATION . . . . . 1

3. EXPERIMENTAL PROCEDURE AND DATA ANALYSIS . . . . . 2

4. RESULTS AND DISCUSSION .................... 2

5. ACKNOWLEDGMENTS ....................... 4

APPENDIX: Direct Experimental Data ......... 9 
Figure 1. Thermal conductivity of glass fiber/epoxy composite support bands, present measurements . . .

Figure 2. Deviations of observed thermal conductivity integrals from those calculated with equation 1. The horizontal bars indicate the temperature span of the measurement for glass fiber/epoxy composite support bands ...........

Figure 3. Comparison of current results to those obtained in 1978 for glass fiber/epoxy composite support bands ................... .

Figure 4. Deviations of 1978 thermal conductivity integrals from values calculated with equation 1 using current coefficients for glass fiber/epoxy composite support bands..............

\section{LIST OF TABLES}

$\underline{\text { Page }}$

Table 1: Characteristics of Specimens .........

Table 2. Thermal Conductivity Values for the Combined Glass Fiber/Epoxy Composite Support Bands of this Research as Calculated from Equation 1........ 
THERMAL CONDUCTIVITY OF GLASS FIBER/EPOXY COMPOSITE SUPPORT BANDS FOR

CRYOGENIC DEWARS, PHASE II

J. G. Hust

National Bureau of Standards

Boulder, CO 80303

The thermal conductivities of three specimens of glass fiber/epoxy composites were measured and reported for the temperature range 4 to $300 \mathrm{~K}$. These specimens were fabricated from two cryogenic dewar support bands. An average conductivity curve for the three specimens is presented. The data for the three specimens are within $+5 \%$ of this average curve. The average curve is compared to a similar curve obtained five years ago in Phase I of this continuing study of composite materials.

Key words: composite; epoxy; glass fiber; low temperature; thermal conductivity

\section{INTRODUCTION}

Composite materials have significant advantages in applications requiring high strength and low thermal conduction. As a consequence, the National Bureau of Standards has been researching the mechanical and thermal properties of composites used in technological applications.

The purpose of this study is to measure the thermal conductivity of several composite specimens fabricated from actual cryogenic support bands. These data, in addition to being valuable for general composite characterization, will be used to calculate the support band portion of the heat leak into an in-flight liquid helium dewar.

\section{MATERIAL AND SPECIMEN CHARACTERIZATION}

This report provides thermal conductivity data on two filament wound glass fiber/epoxy support bands. The bands are used as support members for the superfluid helium dewar to be used in the Cosmic Background Explorer (COBE) Observatory. Three specimens were fabricated from these bands by sectioning the straps. The cut pieces were epoxied together to form the final specimens measured. The characteristics of these specimens are given in Table 1.

Additional fabrication and characterization details can be found in the report of Phase I of this work by Hust and Arvidson (1978). The supplier of these bands has indicated that the fabrication materials and procedures are very similar to the previously measured bands. It is noted, however, that the above densities of the new bands are about $4 \%$ lower than those measured previously. The densities previously measured (four specimens) ranged from 2.09 to $2.12 \mathrm{~g} / \mathrm{cm}^{3}$. Also the coloration of the two sets is considerably different. The bands measured in 1978 are dark brown, while the current bands are amber.

One additional difference between the current specimens and those previously measured is the thickness. It has been found that the optimum accuracy for this apparatus with low conductivity specimens is obtained at a lower thickness than 
Table 1. Characteristics of Specimens

\begin{tabular}{|c|c|c|c|c|c|c|c|}
\hline \multirow[b]{2}{*}{$\begin{array}{l}\text { Part } \\
\text { Number }\end{array}$} & \multirow[b]{2}{*}{$\begin{array}{l}\text { Band } \\
\text { Serial } \\
\text { Number }\end{array}$} & \multirow[b]{2}{*}{$\begin{array}{l}\text { Specimen } \\
\text { Number }\end{array}$} & \multicolumn{3}{|c|}{$\begin{array}{c}\begin{array}{c}\text { Specimen Dimensions } \\
(\mathrm{cm})\end{array} \\
\end{array}$} & \multirow[b]{2}{*}{$\begin{array}{l}\text { Weight } \\
\text { (g) }\end{array}$} & \multirow[b]{2}{*}{$\begin{array}{l}\text { Density } \\
\left(\mathrm{g} / \mathrm{cm}^{3}\right)\end{array}$} \\
\hline & & & Thickness & $\begin{array}{c}\text { Width } \\
A\end{array}$ & $\begin{array}{c}\text { Width } \\
\text { B }\end{array}$ & & \\
\hline $151490-1$ & $25 \mathrm{~A}$ & $25-A$ & 0.540 & 1.879 & 1.737 & 3.562 & 2.02 \\
\hline $151490-1$ & $25 \mathrm{~A}$ & $25-B$ & 0.644 & 1.920 & 1.735 & 4.358 & 2.03 \\
\hline 151490-1 & 26 & 26 & 0.540 & 1.905 & 1.798 & 3.707 & 2.00 \\
\hline
\end{tabular}

The fibers are S-2 glass (essentially the same as MIL SPEC S901) and the resin is SCI REZ 081. (The previously used resin is SCI REZ 080). The use of trades is necessary for material identification. No endorsement or approval of the product is intended.

previously used. The thickness is in the direction of the fibers and in the direction of the measured heat flow. The previous specimens were measured at about $2.4 \mathrm{~cm}$ thickness, while these at about $0.6 \mathrm{~cm}$ thickness. In Table 1 , the width (A) is parallel to the pieces cut from the strap while width $B$ is perpendicular to the pieces (both are perpendicular to the glass fibers and heat flow). Previous measurements on similar composites indicate that this change in form factor should not affect the results of these measurements beyond the stated uncertainty.

\section{EXPERIMENTAL PROCEDURE AND DATA ANALYSIS}

The measurements on the test specimens are performed in an apparatus previously described by Hust and Arvidson (1978). The accuracy, based on considerable experience with this apparatus, including the measurement of Standard Reference Materials, is given as $10 \%$. The imprecision of the data has been found to be near $1 \%$ for a given specimen mounting and no more than $5 \%$ for specimen remounting in the apparatus.

The experimental data are actually thermal conductivity integral values, since large temperature differences are used. The methods used to analyze these data to obtain thermal conductivity values are described by Hust and Lankford (1982). It is to be noted that the differences between the values obtained by the usual difference technique and the values obtained by the thermal conductivity integral technique are quite small because of the monotonic nature of the curve for this material.

\section{RESULTS AND DISCUSSION}

The direct experimental data for the three specimens are presented in the appendix. These data were analyzed by both the difference method and the thermal conductivity integral method. The results of these calculations for all of the data are illustrated in Fig. 1. The function chosen for the integral method is 


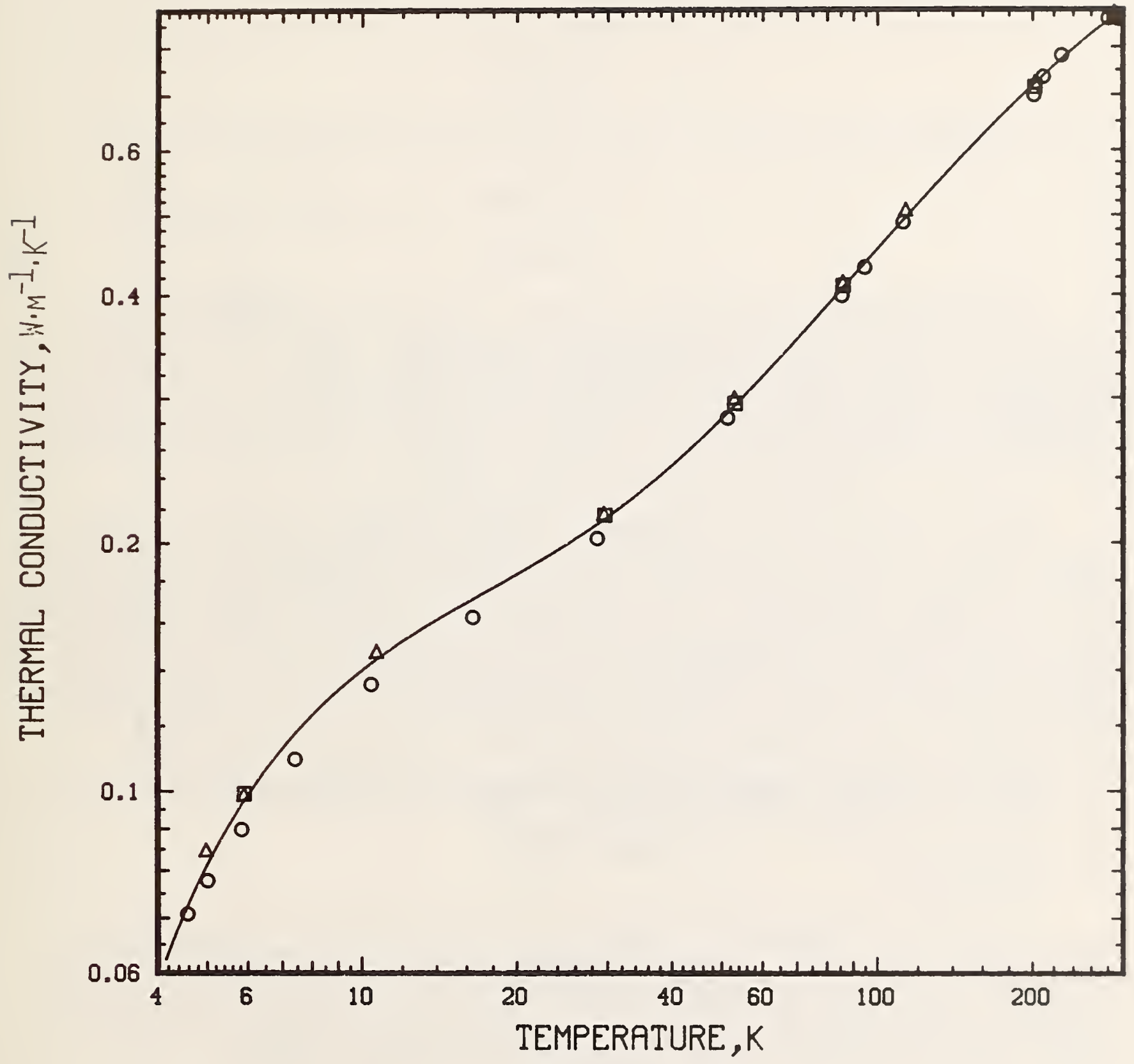

Figure 1. Thermal conductivity of glass fiber/epoxy composite support bands, present measurements.

0 = Specimen $25-B$

$\Delta=$ Specimen 25-A $\}$ From difference method.

$0=$ Specimen 26

Solid line $=$ values from equation 1 


$$
K(T)=\sum_{j=1}^{5} A_{j}[\ln (T+1)]^{i}
$$

where $K(T)$ is thermal conductivity, $T$ is temperature in Kelvin, and the $A_{j}$ resulting from the least squares fit are:

$$
\begin{aligned}
& A_{1}=-0.30274718 \\
& A_{2}=0.43272669 \\
& A_{3}=-0.18794186 \\
& A_{4}=0.034528862 \\
& A_{5}=-0.0021756062
\end{aligned}
$$

The deviations of the measured thermal conductivity integrals from those calculated from (1) are illustrated in Fig. 2. As can be seen, these three specimens are nearly the same in thermal conductivity. However, the differences are somewhat larger than for the specimens measured previously. The current differences are $\pm 5 \%$ from the mean at 10 temperatures, decreasing to $+1 \%$ at higher temperatures. The previous results showed differences of about $+2 \overline{\%}$ from the mean at low temperatures and $+4 \%$ at higher temperatures.

More important are the differences between the means of the two sets of measurements. Figures 3 and 4 compare the two sets of data. The present values differ from the earlier results by as much a $27 \%$ at low temperatures, decreasing to $7 \%$ at higher temperatures. The reason for this difference is not understood. It may be connected with the observed difference in density referred to earlier. The thickness difference between the two sets of specimens may be partly responsible for the difference. However, it is noted that Kapitza resistance differences should not be effective to such high temperatures, and the ordinary radiative thickness effect should be most effective at the higher temperatures.

Table 2 contains values of thermal conductivity as calculated from eq. (1) for the present specimens.

\section{ACKNOWLEDGMENTS}

The author acknowledges the support of Dr. Steve Castles of the Goddard Space Flight Center, NASA. Al so acknowledged is Structural Composite Industries for supplying the material and characterization data. Finally I thank Richard Hopkins of Ball Aerospace Systems Division (BASD) for expediting specimen acquisition and miscellaneous interactions with the sponsor and supplier. BASD is under contract to build the helium dewar for the COBE Observatory.

Hust, J. G. and Arvidson, J. M., Thermal Conductivity of Glass Fiber/Epoxy Composite Support Bands for Cryogenic Dewars, Report 275.03-78-2, 80 pages, 1978.

Hust, J. G. and Lankford, A. B., Comments on the Measurement of Thermal conductivity and Presentation of a Thermal Conductivity Integral Method, International Journal of Thermophysics, Vol. 3, No. 1, 67-77 (1982). 


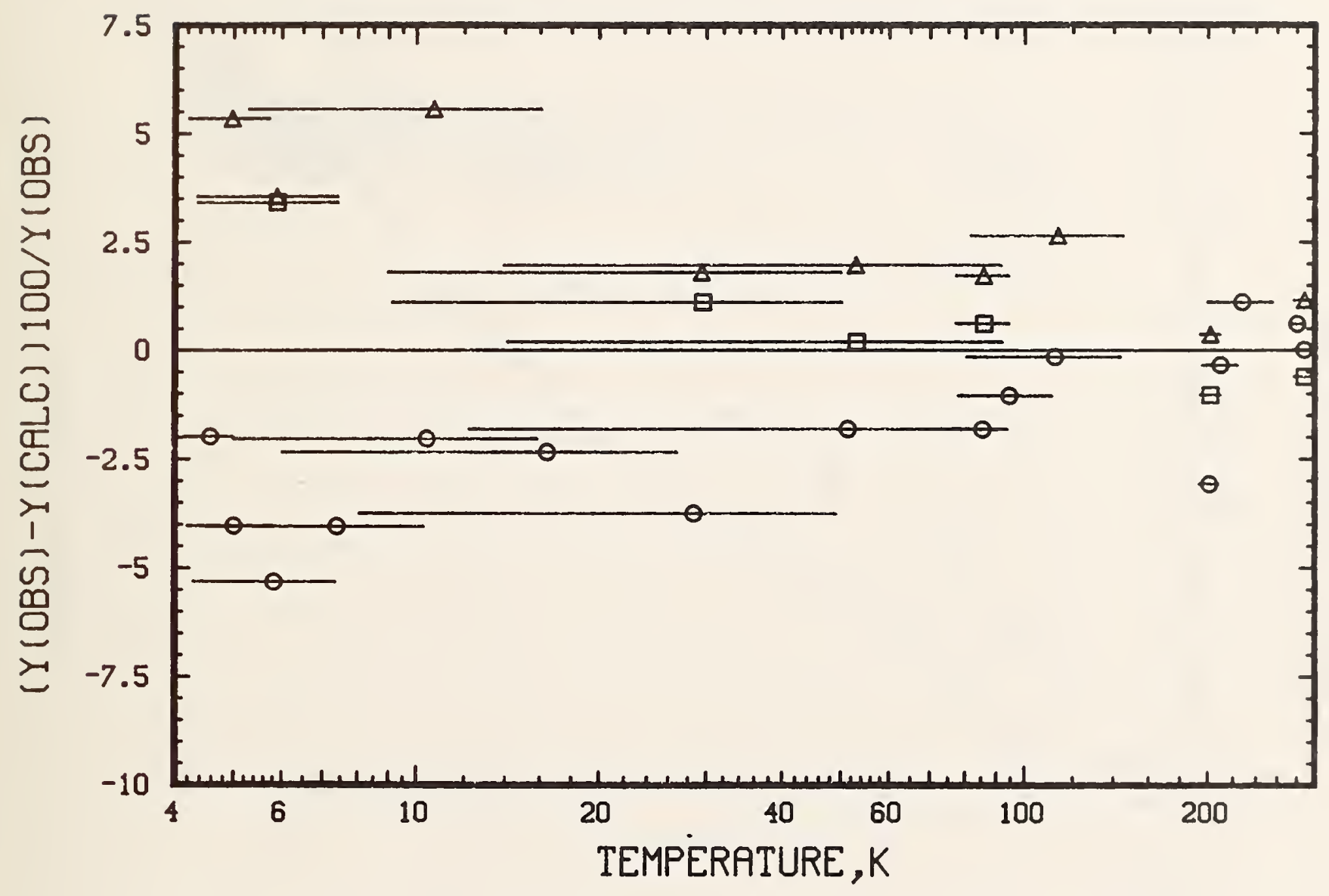

Figure 2. Deviations of observed thermal conductivity integrals from those calculated with equation 1 . The horizontal bars indicate the temperature span of the measurement for glass fiber/epoxy composite support bands.

$$
\begin{aligned}
& \mathbf{O}=\text { Specimen } 25-\mathrm{B} \\
& \mathbf{\Delta}=\text { Specimen } 25-\mathrm{A} \\
& \mathbf{0}=\text { Specimen } 26
\end{aligned}
$$




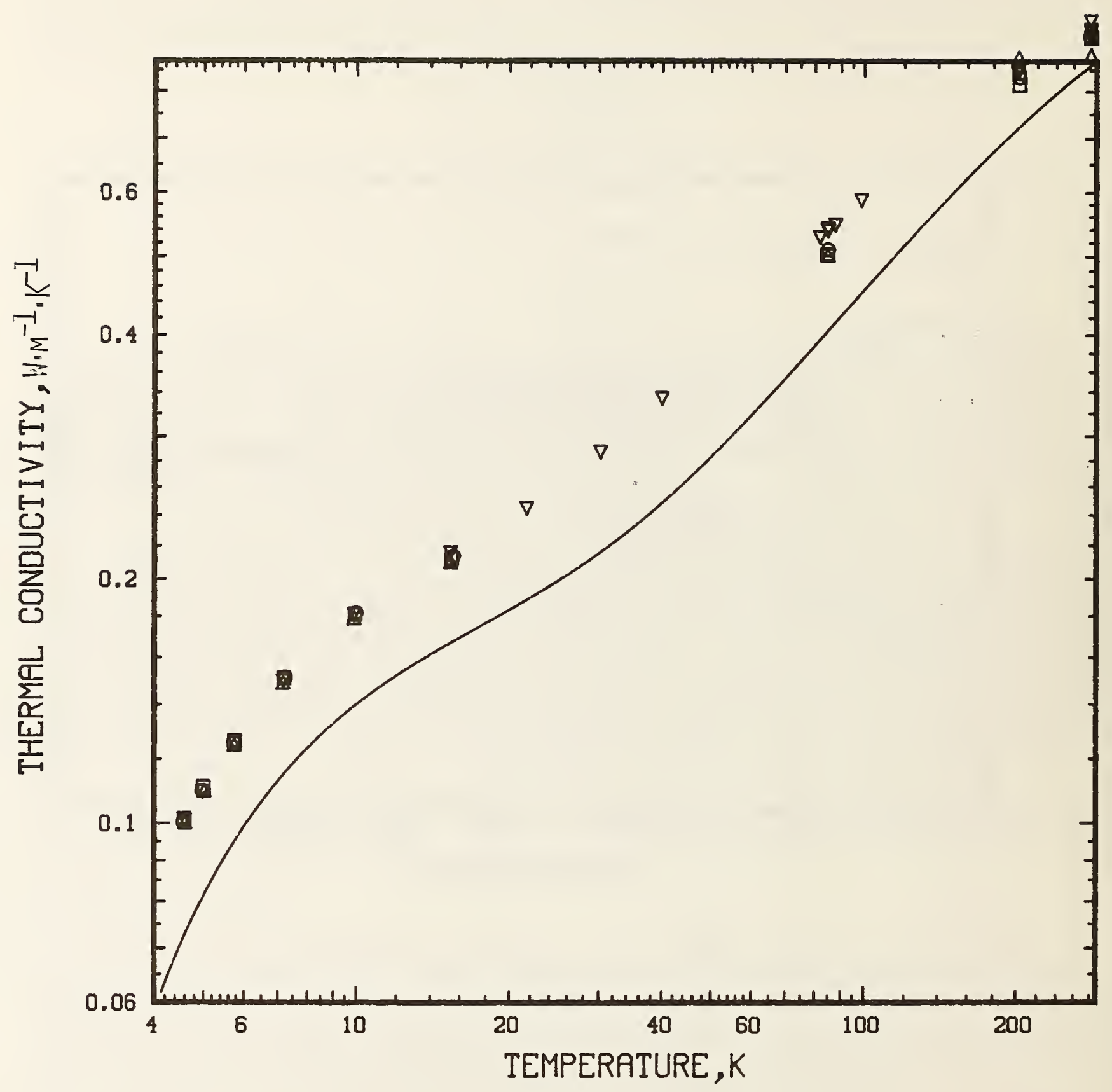

Figure 3. Comparison of current results to those obtained in 1978 for glass fiber/epoxy composite support bands.

Discrete symbols $=1978$ results on four specimens

Solid line = current results 


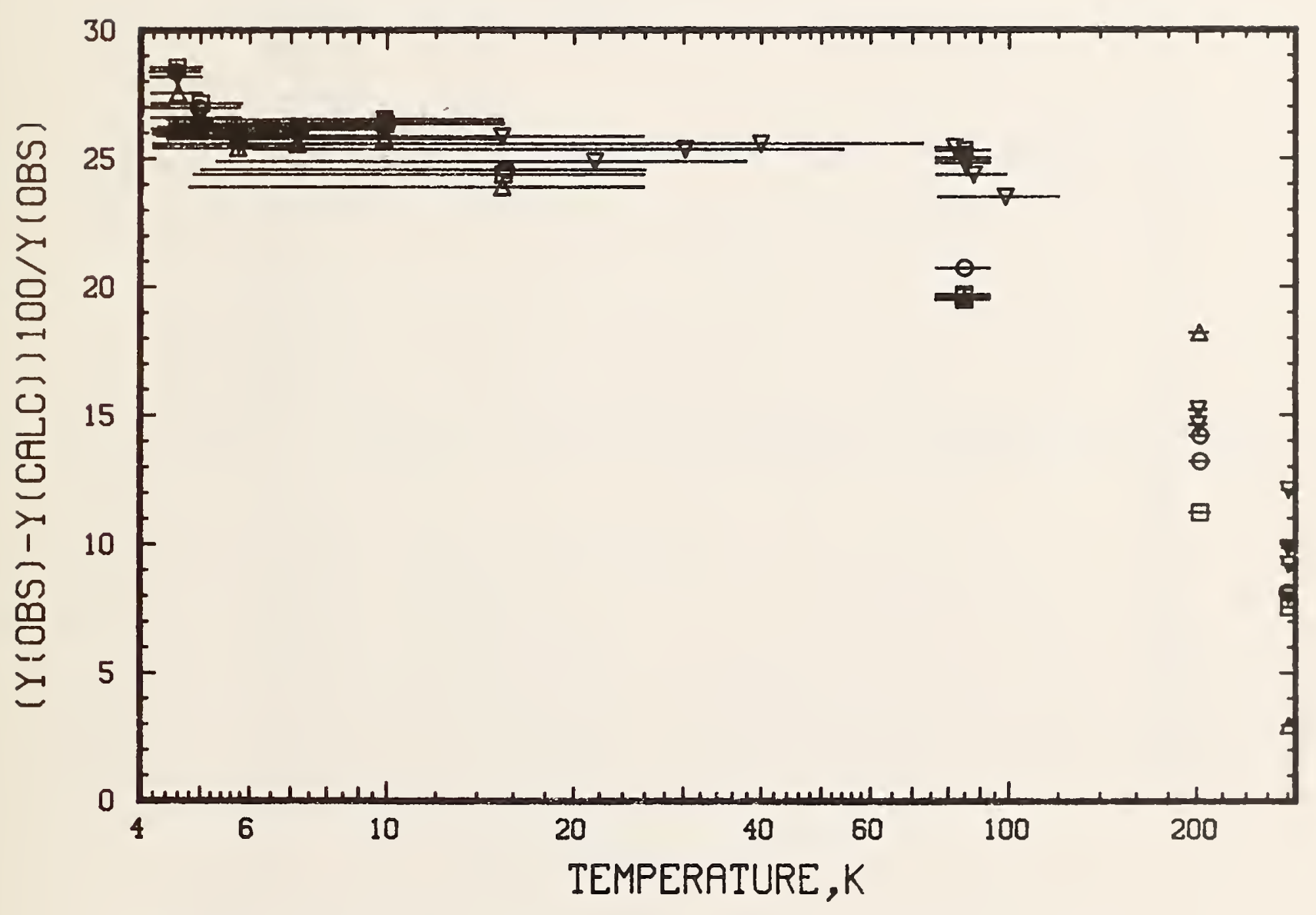

Figure 4. Deviations of 1978 thermal conductivity integrals from values calculated with equation 1 using current coefficients for glass fiber/epoxy composite support bands. 
Table 2. Thermal Conductivity Values for the Combined Glass Fiber/Epoxy Composite Support Bands of this Research as Calculated from Equation 1.

Temperature

$(\mathrm{K})$

\begin{tabular}{rl}
\hline 4 & 0.0584 \\
5 & 0.0814 \\
6 & 0.0990 \\
8 & 0.124 \\
10 & 0.140 \\
\hline 15 & 0.165 \\
20 & 0.183 \\
30 & 0.215 \\
40 & 0.248 \\
50 & 0.285 \\
\hline 60 & 0.318 \\
80 & 0.388 \\
100 & 0.454 \\
150 & 0.600 \\
200 & 0.719 \\
\hline 300 & 0.890 \\
\hline
\end{tabular}

Thermal Conductivity

$\left(\mathrm{W} \cdot \mathrm{m}^{-1} \cdot \mathrm{K}^{-1}\right)$ 


\section{APPENDIX}

\section{Direct Experimental Data}

For potential future reference it is desirable to record the direct experimental data. These data along with some pertinent calculated quantities are recorded in the following format for each run:

1st line - specimen identification, data, time

2nd line - variable identification

3rd line - variable values

Remaining lines are identified - thermal conductivity is expressed in $\mathrm{W} \cdot \mathrm{m}^{-1} \cdot \mathrm{K}^{-1}$.

Abbreviations in the 2nd line have the following meaning:

HTR VOLT = voltage across heater in volts

HTR CURR = current through heater in milliamps

DELTAE = Emf of differential thermocouple between blocks in microvolts

$\mathrm{BTH}=$ code indicating the cryogen

$=1 .=$ liquid helium

=2. = liquid hydrogen

=3. = liquid nitrogen

$=4$. $=$ dry ice - alcohol mixture

=5. = ice - water mixture

PRB = code indicating the probe

$=1$. $=$ bonded probe

= 2 . $=$ compression probe

DIAMETER = equivalent diameter for specimen cross-section in centimeters

TEMP $=$ cryogen temperature in Kelvins

DELE ZERO = spurious emf of differential thermocouple at zero power from heater in microvolts

DELTA $X=$ specimen length in centimeter 


\section{APPENDIX (continued)}

Specimen 25-B

THERMAL CONDUCTIVITY TATA FOR EPOX/FIB STRAP $25-8,6 / 7 / 83,1400$

$\begin{array}{cccccccccc}\text { HTR VRLT } & \text { HTR CURR } & \text { OELTA E } & \text { BTH } & \text { PRB } & \text { DIAMETER } & \text { TEMP } & \text { OELE ZERC DELTA X } \\ 8.5277 & 42.8800 & 299.17 & 3 . & 2 . & 1.9690 & 76.00 & 0.00 & .5439\end{array}$

THERMAL CONDUCTIVITY

$\triangle T$ A MEAN TEMP DF

WITH BLOCK TEMPS OF

$3988 E+00$

UNCERTAINTY

5. RERCENT

93.695 AND 76.936 DELT=

$0 / T$. OELT (TMTAL) $=.2557$ TE $^{-03}$ (EMPTY PRORE) $=.3469 E-04$

HEATER RESISTANCE = 198.874 AND HEATER VOLTAGE =

-3161E+001 86. PCT)

(SPECIMEN) = .2210E-03

$.8528 E+01$

THERMAL CONDUCTIVITY OATA FRR EPOX/FIB STRAP $25-R, 6 / 7 / 83,1530$

$\begin{array}{llccccccc}\text { HTR VOLT } & \text { HTR CURR } & \text { OELTA F } & \text { BTH } & \text { PRB } & \text { OIAMETER } & \text { TEMP } & \text { DELE ZERD DELTAX } \\ 12.4213 & 62.4680 & 600.21 & 3 . & 2 . & 1.9690 & 76.00 & 0.00 & .3439\end{array}$

THE RMAL CONDUCTIVITYO

AT A MEAN TEMP DF

$.4314 E+00$ UNCERTAINTY $=$

5. PERCENT

HITH BLOCK TEMPS OF 94.432

110.877 AND 77.986 DELT

HERE TOTAL HEAT FLOH= .7759E+00 ANO SPEC HEAT FLOW=

Q/T.DELT(TOTAL) $=.2498 E-03$ (EMPTY PROAE) $=.3377 E-04$

HEATER RESIST ANCE $\approx$ 198.843 AND HEATFR VOLTAGE $=$

32.891

$.6710 E+00(86 . P(T)$

(SPECIMEN) $=.2161 \mathrm{E}-03$ $.1242 E+02$

THERMAL CONOUCTIVITY OATA FOR EPOX/FI8 STRAP $25-R, 6 / 7 / 83,1730$

$\begin{array}{lllllllll}\text { HTR VRLT } & \text { HTR CURR } & \text { OELTA E } & \text { BTH } & \text { PRB } & \text { DIAMETER } & \text { TEMP } & \text { OELE ZERO OELTA X } \\ 18.3937 & 92.4430 & 1199.70 & 3 . & 2 . & 1.9690 & 76.00 & 0.00 & .3439\end{array}$

THERMAL CONDUCTIVITY $=\quad .4896 E+00 \quad$ UNCERTAINTY $=\quad$ 5. PERCENT

AT MEAN TEMP OF
WITH RLOCK TEMPS OF

143.770 ANO BO.353 DELT

O/T. DELT(TOTAL) $=.2393 E-03$ (EMPTY PROBE) $=.3266 E-04$

HEATER RESISTANCE: 198.973 AND HEATER VDLTAGE=

$1468 E+01(86 . P C T)$

(SPECIMEN) $=.2006 E=03$

$.1839 E+02$

THERMAL CONDUCTIVITY OATA FOR EPOX/FIB STPAP 25-B,6/8/83,1255

HTR VOLT HTR CURR DELTA E - BTH ... PRB DIAMETER TEMP . OELE ZFRO OELTA X

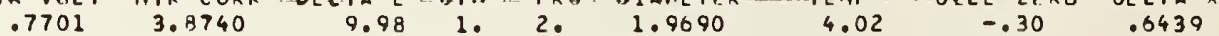

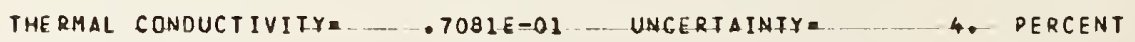

AT A MEAN TEMP DF

WITH BLOCK TEMPS OF 4.577

4.996 ANO

4.158 OELT:

.838

HERE TOTAL HEAT FLOHE .2983E-02 AND SPEC HEAT FLTHE .2807E-02( 94 . PCT)

Q/T. OELTITOTAL) $=.7776 E-03$ (EMPTY PROBE) $=.4587 E-04 \quad$ (SPECIMEN) $=.7317 E-03$

HEATER RESISTANCE $=199.797$ ANO HEATER VOLTAGE= $17701 \mathrm{~T}+00$ 
APPEIIDIK (continued)

Specimen 25-B

THEPMAL CINDUCTIVITY DATA FDP EPOX/FIR STRAP 25-R,6/8/83,1305

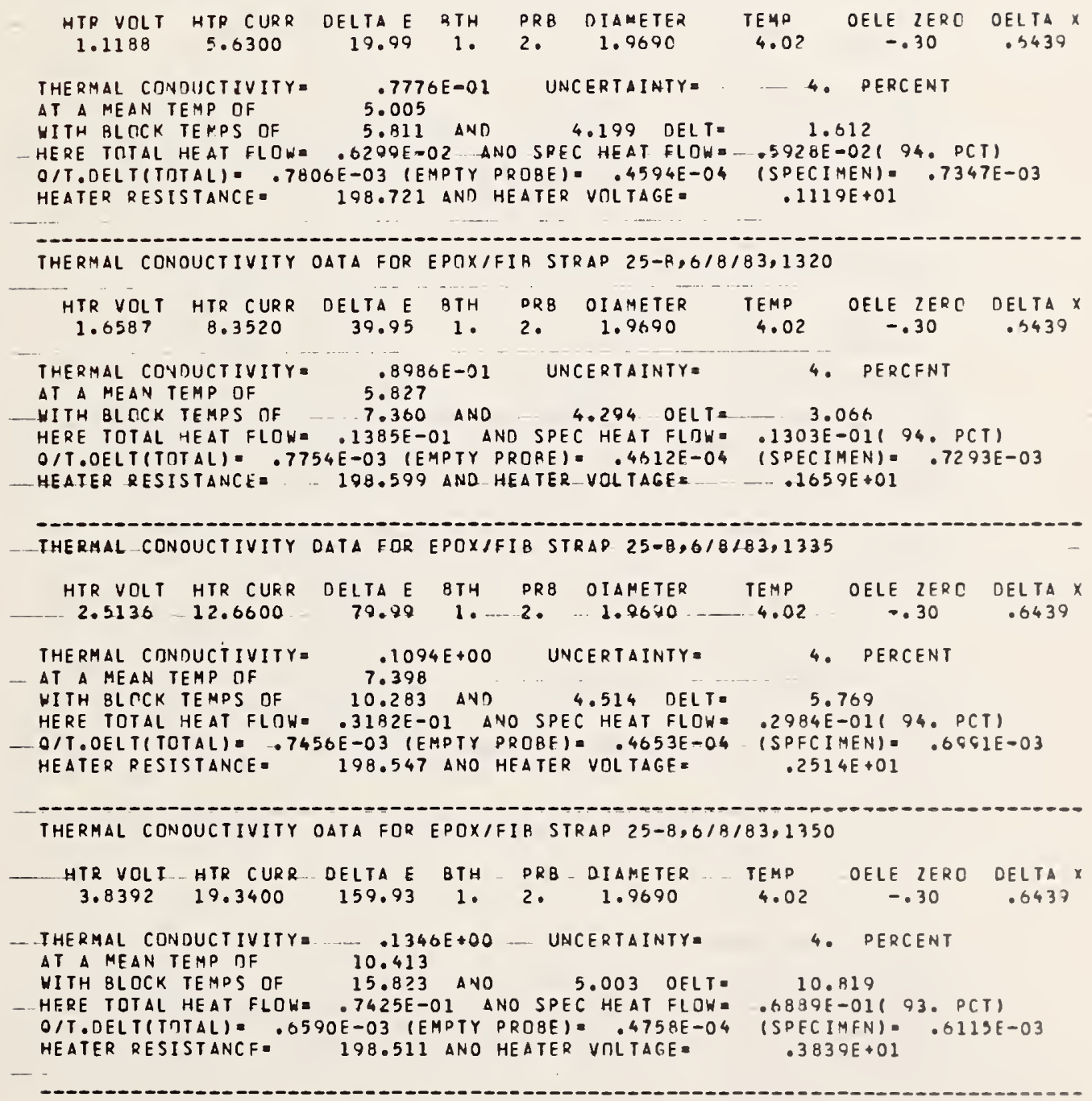




\section{APPENDIX (continued)}

\section{Specimen 25-B}

THERMAL CONDUCTIVITY OATA FOR EPOX/FIB STRAP 25-R,6/8/R3, L410

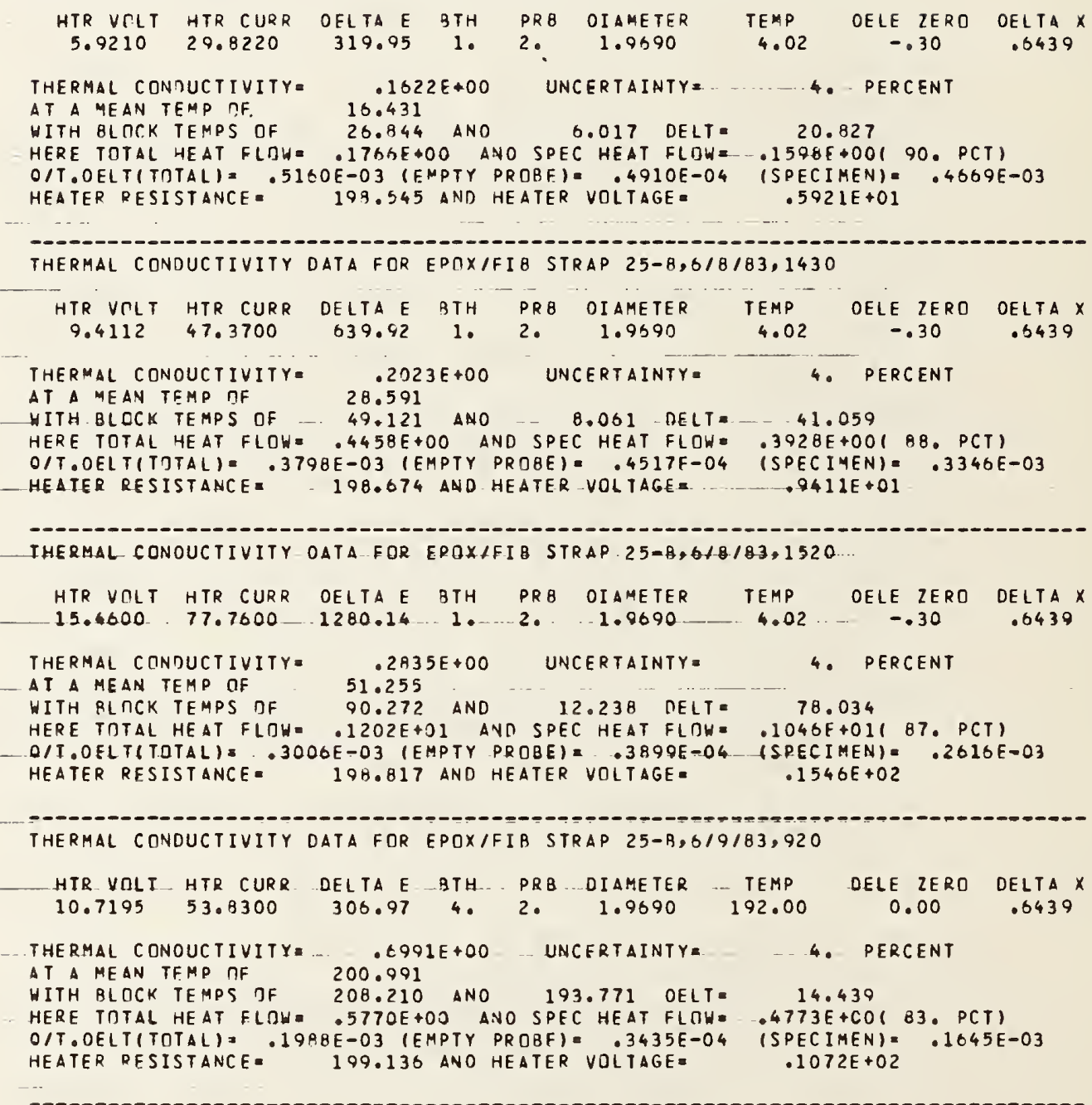




\section{APPENDIX (continued)}

Specimen 25-B

THERMAL CONDUCTIVITY OATA FOR EPIX/FIB STRAP 25-8,5/9/83,1155

$\begin{array}{llccccccc}\text { HTR VCLT } & \text { HTR CURR } & \text { OELTAE } & \text { ATH } & \text { PRB } & \text { DIAHETER } & \text { TEMP } & \text { DELF ZERO OELTA K } \\ 15.3225 & 76.9400 & 599.62 & 4 . & 2 . & 1.9690 & 192.00 & 0.00 & .6439\end{array}$

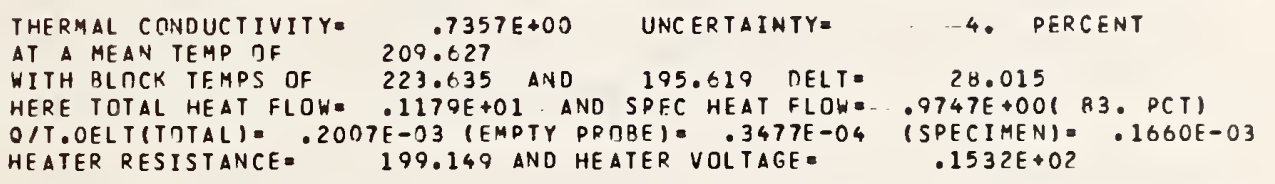

THERMAL CONDUCTIVITY OATA FOR EPOX/FIB STRAP 25-8,6/9/83,1515

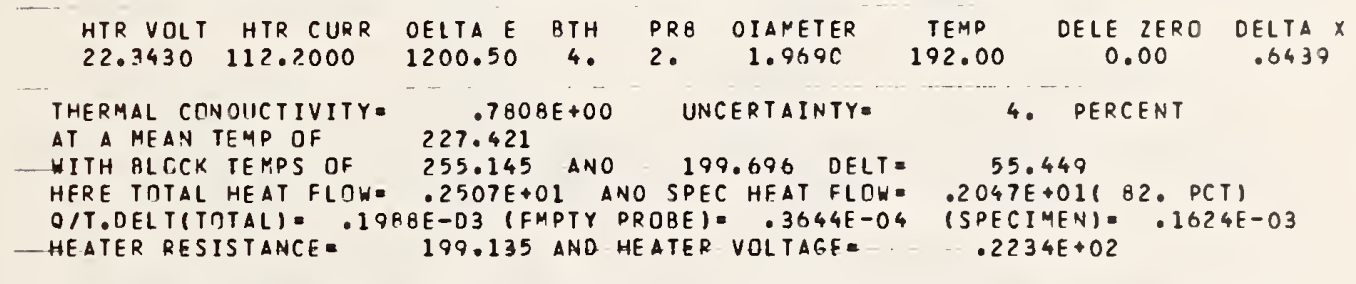

THERMAL CONOUCTIVITY DATA FDR EROXIFIB STRAP $25-8,6110183,1110$

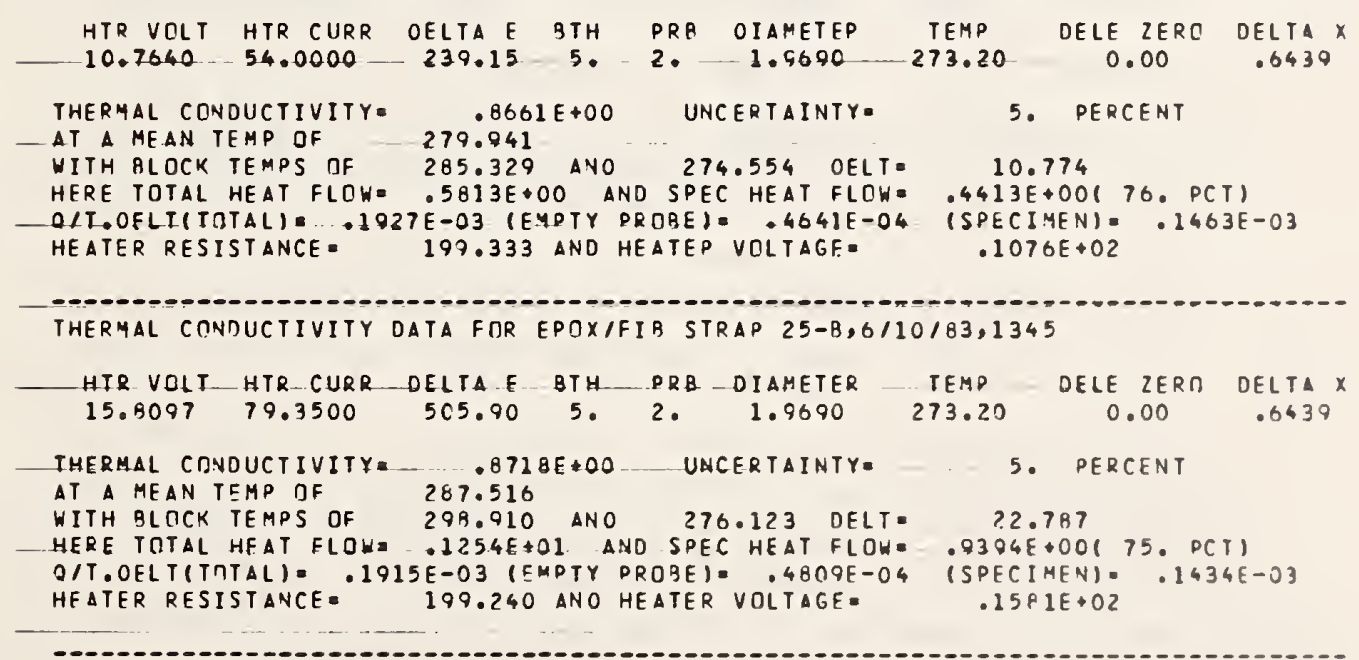




\section{APPENDIX (continued)}

Specimen 25-A

THERMAL CONOUCTIVITY DATA FOR EPOX/FIB STRAP 25-A,6/13/83,1118

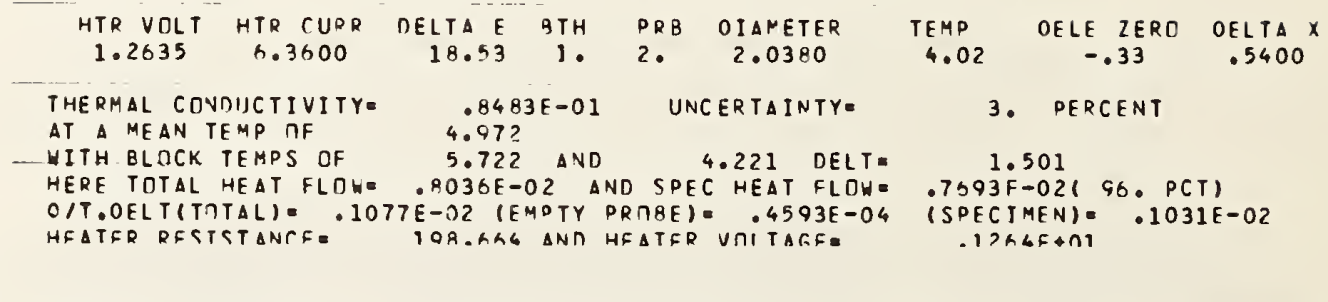

THERMAL CONDUCTIVITY DATA FIRR EPTX/FI8 STRAP 25-A, B/13/83,1135

$\begin{array}{ccrrlcccc}\text { HTR VDLT } & \text { HTR CURR } & \text { DELTAE } & \text { BTH } & \text { PRA } & \text { DIAMETER } & \text { TEMP } & \text { DELE ZERC } & \text { OELTA } X \\ 1.9521 & 9.8300 & 40.00 & 1 . & 2 . & 2.0380 & 4.02 & -.33 & .5400\end{array}$

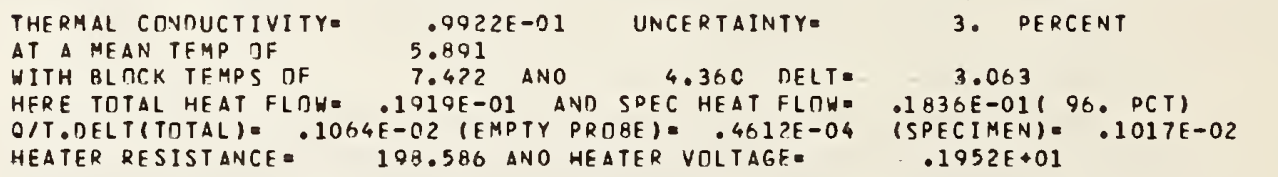

THERMAL CONDUCTIVITY OATA FOR EPOX/FI8 STRAP $25-4,6 / 13 / 83,1145$

$\begin{array}{ccrrrrrrr}\text { HTR VDLT } & \text { HTR CURR } & \text { OELTAE } & \text { BTH } & \text { PRA } & \text { DIAMETER } & \text { TEMP } & \text { OELE ZERO OELTAX } \\ 4.4901 & 22.6200 & 160.00 & 1 . & 2 . & 2.0380 & 4.02 & -.33 & .5400\end{array}$

THERMAL CONOUCTIVITY= $10.1477 E+00$ UNCERTAINTY=

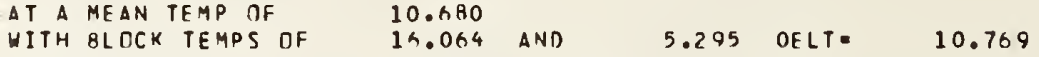

HERE TDTAL HEAT FLIWE .1016E+00 ANO SPEC HEAT FLOHE .9610E-011 95. PCT)

O/T.OELT(TOTAL)=.8831E-03 (EMPTY PROBE)=.4757E-04 ISPECINEN)=.8355E-03

HEATER RESISTANCE = 198.501 ANO HEATER VOLTAGE= .4490E+01

THERMAL CONOUCTIVITY TATA FIR EPOX/FIR STRAP 25-4,6/13/83,1155

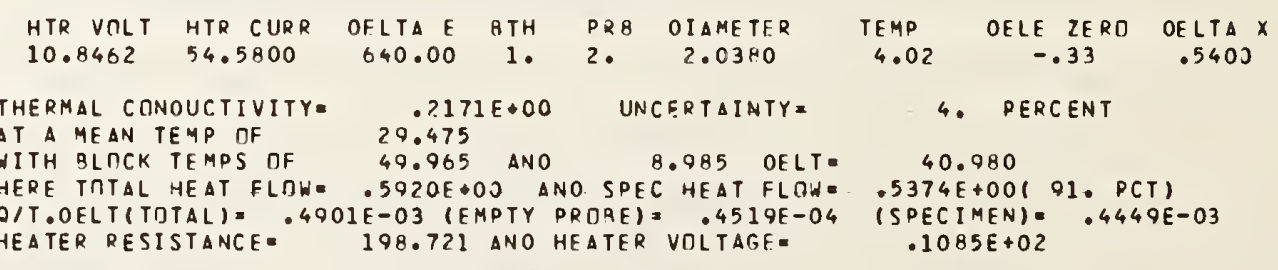




\section{APPENDIX (continued)}

\section{Specimen $25-\mathrm{A}$}

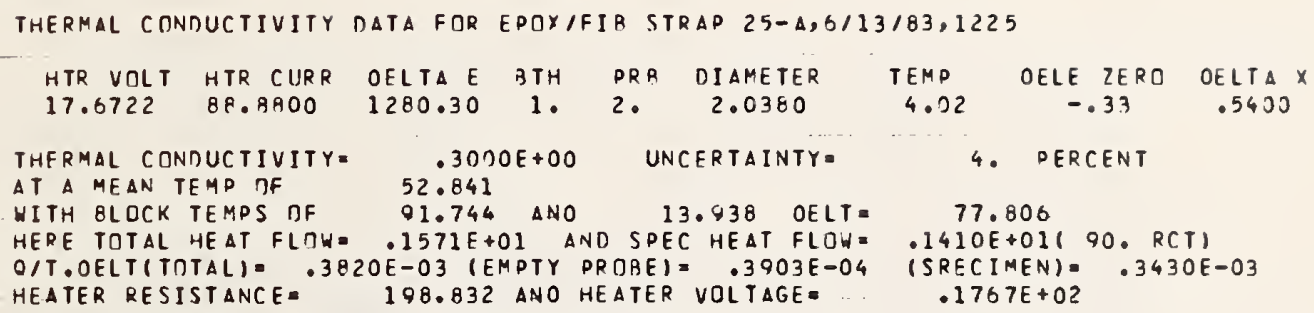

THERMAL CONOUCTIVITY DATA FOR EPOX/FIB STRAR 25=A,6/13/83,1505

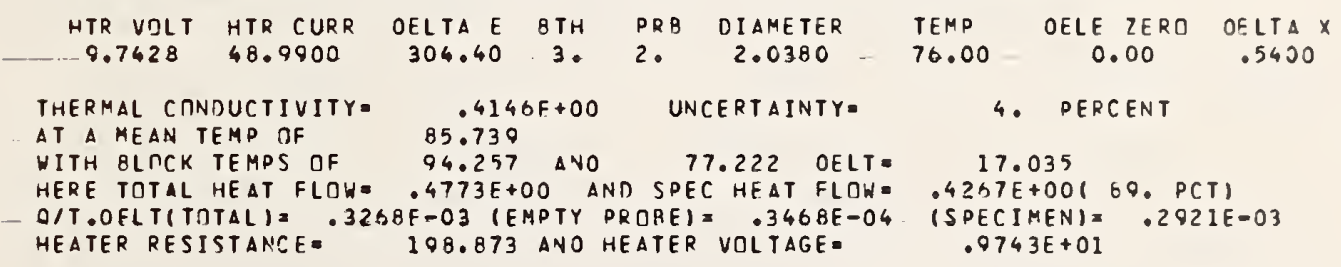

THERMAL CONDUCTIVITY OATA FOR EPOX/FIB STRAR 25-A,6/13/83,1630

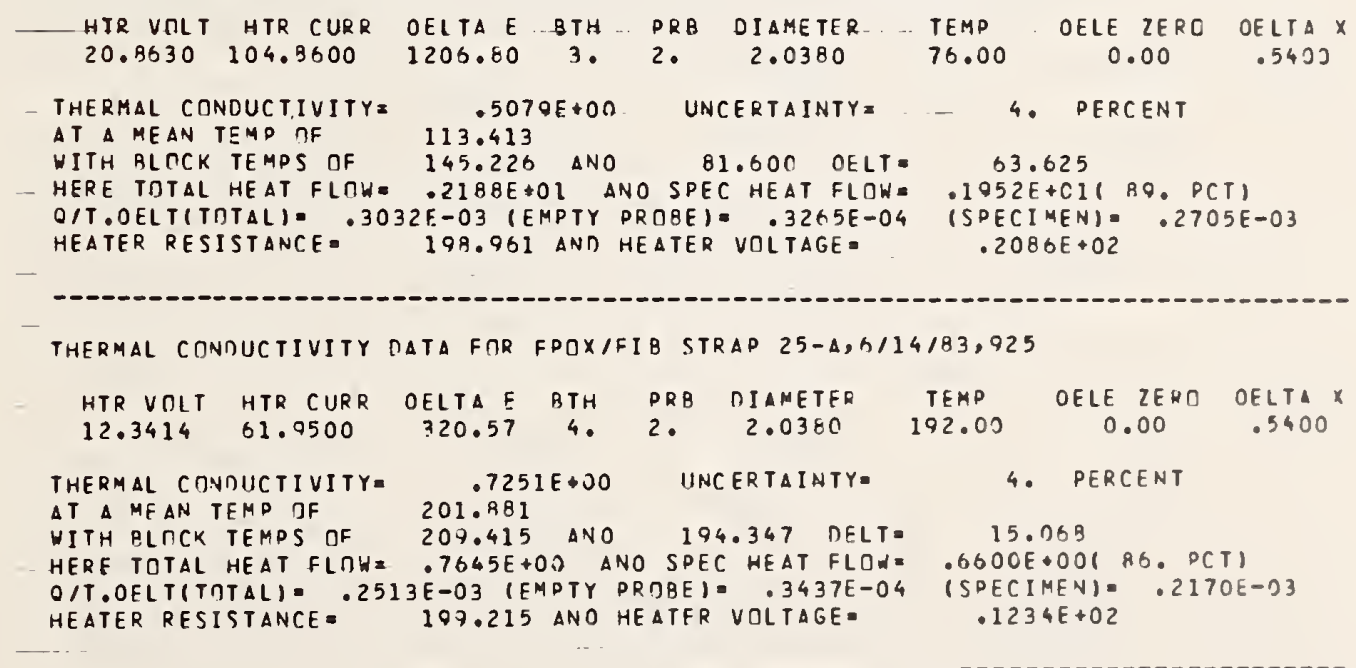




\section{APPENDIX (continued)}

Specimen $25-\mathrm{A}$

THERMAL CONDUCTIVITY DATA FOR EPOX/FIB STRAP $25-A, 6 / 14 / 83,1205$

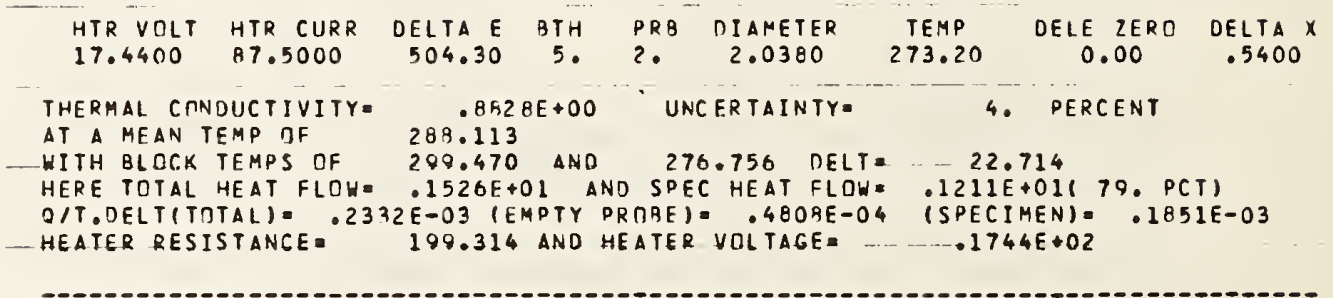




\section{APPENDIX (continued)}

\section{Specimen 26}

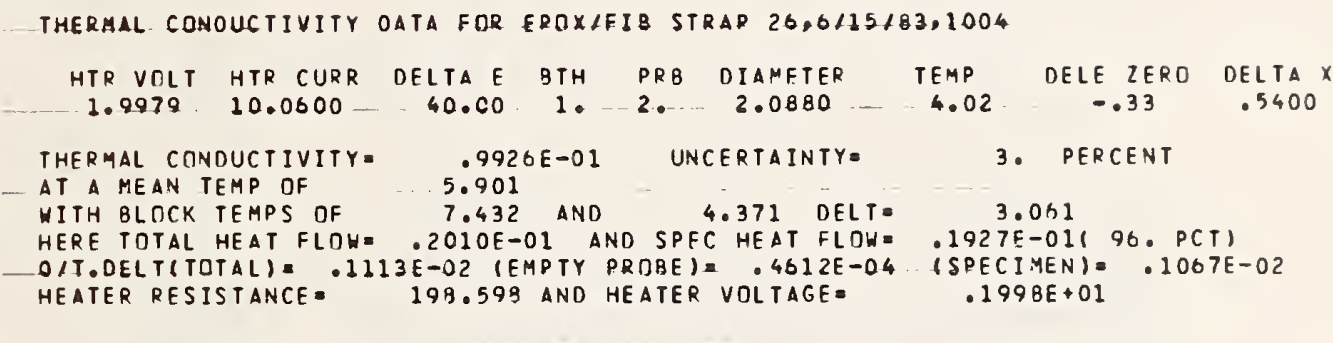

THERMAL CONDUCTIVITY DATA FDP EPDX/FIB STRAP $2 t, t / 15 / 83,1030$

$\begin{array}{llccccccc}\text { HTR VILT } & \text { HTR CURR DELTA E } & \text { BTH } & \text { PRB } & \text { DIAMETER } & \text { TEMP } & \text { DELE ZERO DELTA X } \\ 11.0648 & 55.7000 & 640.00 & 1 . & 2 . & 2.0880 & 4.02 & -.33 & .5400\end{array}$
THERMAL CONDUCTIVITY=
$\triangle T$ A MEAN TFMP OF
$.2161 E+00$
UNCERTAINTY
29.615 AND
9.131 DELTE
4. PERCENT
HERE TDTAL HEAT FLDHE .6163E+00 AND SPEC HEAT FLDW
Q/T.DELT(TOTAL) $=.5080 E-03$ (EMPTY PRDRE) . .4519E-04
HEATER RESISTANCE = 199.650 AND HEATER VOLTAGE=
40.967
$.5615 E+00191 . P(T)$
(SPECIMEN) $=.4628 E-03$
$.1106 E+02$

THERMAL CONDUCTIVITY DATA FOR EPOX/FIB STRAP $26,6 / 15 / 83,1100$

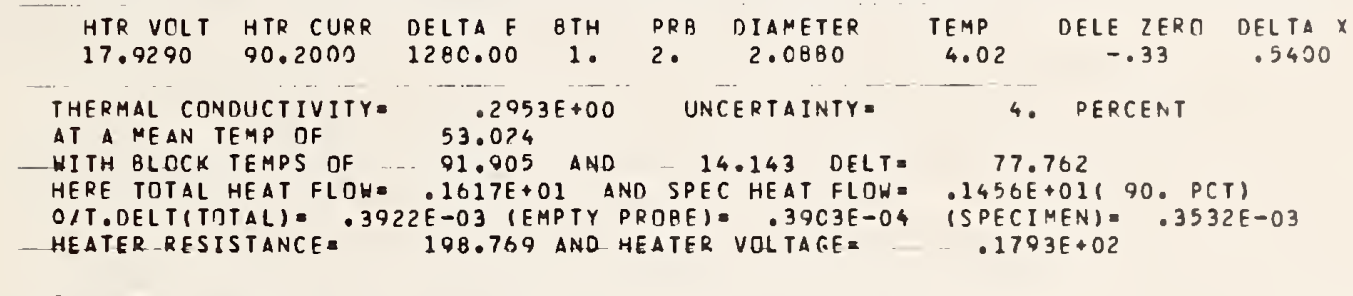

THERMAL CONDUCTIVITY OATA FOR EPOX/FIB STRAP $26,6 / 15 / 83,1330$

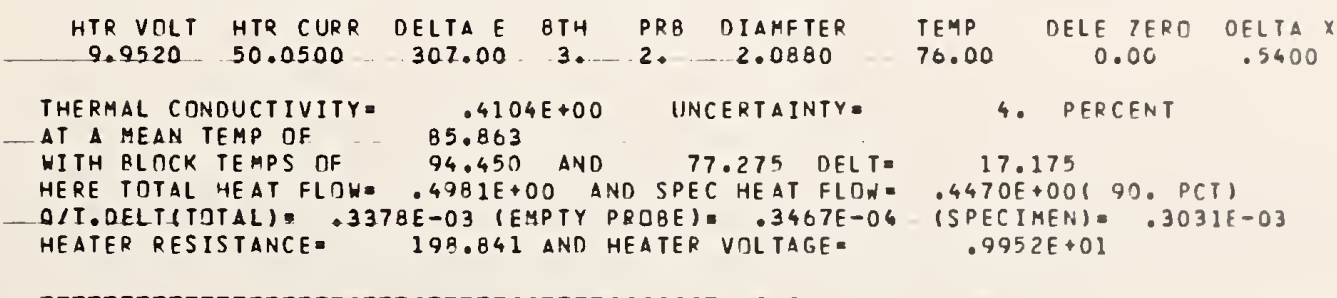




\section{APPENDIX (continued)}

\section{Specimen 26}

THERMAL CONDUCTIVITY DATA FOR EPOX/FI8 STRAP $26,6 / 15 / 83,1900$

$$
\begin{aligned}
& \text { HTR VILT HTR CURR DELTA E BTH PRB OIAMFTER TEMP DELE ZERO DELTA X }
\end{aligned}
$$

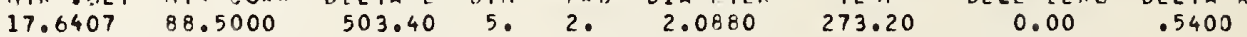

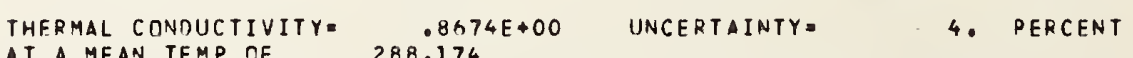

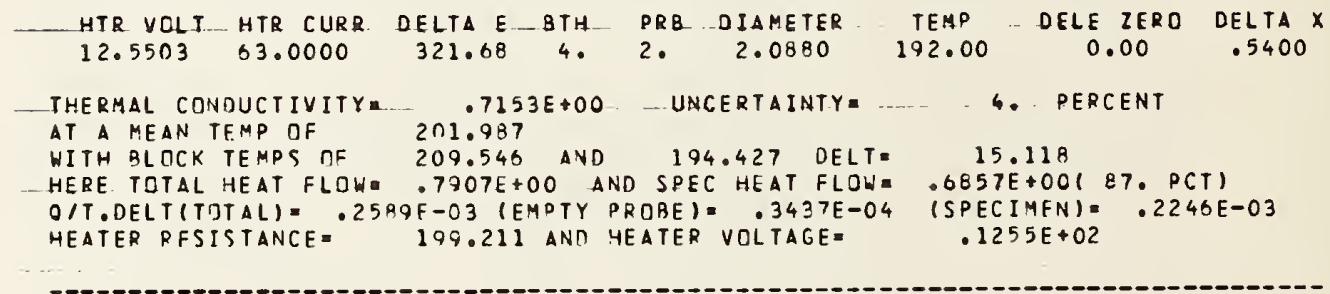


THERMAL CONDUCTIVITY OF GLASS FIBER/EPOXY COMPOSITE SUPPORT BANDS FOR CRYOGENIC DEWARS, PHASE II

5. AUTHOR(S)

J. G. Hust

6. PERFORMING ORGANIZATION (If joint or other than NBS, see instructions)

7. Contract/Grant No.

NATIONAL BUREAU OF STANDARDS

Contract No. S-12425-C

DEPARTMENT OF COMMERCE

8. Type of Report \& Period Covered

WASHINGTON, D.C. 20234

Final, Jan-Sep 1983

9. SPONSORING ORGANIZATION NAME AAD COMPLETE ADDRESS (StreEt, City, StatE. ZIP)

National Aeronautics and Space Administration

Goddard Space Flight Center

Greenbelt, Maryland 20771

10. SUPPLEMENTARY NOTES

Document describes a computer program; SF-185, FIPS Software Summary, is attached.

11. ABSTRACT (A 200-word or less factual summary of most significant information. If document includes a significant bibliography or literature survey. mention it here)

The thermal conductivities of three specimens of glass fiber/epoxy composites were measured and reported for the temperature range 4 to $300 \mathrm{~K}$. These specimens were fabricated from two cryogenic dewar support bands.

An average conductivity curve for the three specimens is presented. The data for the three specimens are within $+5 \%$ of this average curve. The average curve is compared to a similar curve obtained five years ago in Phase I of this continuing study of composite materials.

12. KEY WORDS (Six to twelve entries; alphobetical order: copitalize only proper nomes; and seporate key words by semicolons) composite; epoxy; glass fiber; low temperature; thermal conductivity

13. AVAILABILITY

XX Unlimited

$\square$ For Official Distribution. Do Not Release to NTIS

$\square$ Order From Superintendent of Documents, U.S. Government Printing Office, Washington, D.C. 20402.

X Order From National Technical Information Service (NTIS), Springfield, VA. 2216I
14. NO. OF

PRINTED PAGES

\section{2}

15. Price 

